\title{
Anatomical and histochemical aspects of zigotic embryo and leaves in 'Coqueiro Anão'
}

\author{
Aspectos anatômicos e histoquímicos de embrião zigótico e folhas em 'Coqueiro Anão' \\ Marlucia Cruz de SantanaI ${ }^{\mathrm{I}}$ Margarete Magalhães Souza ${ }^{\mathrm{II}}$ Telma Nair Santana Pereira ${ }^{\mathrm{II}}$ \\ Sílvio Lopes Teixeira ${ }^{\text {II }}$
}

\begin{abstract}
The paper provides information about histochemical staining reactions in leaves and embryos of 'Coqueiro Anão' (Cocos nucifera). It was compared in vitro coconut and autotrophic palm leaves. Reactions for insoluble polysaccharides and acidic compounds, protein, extractable lipids, lignin and other classes of compounds were tested using histochemical tests. None sample gave positive reaction for lignin and phenolic compounds. All the samples gave positive reaction for protein, starch and insoluble polysaccharides while acidic compounds were positive only in in vitro leaves. Both in vitro and autotrophic leaves gave positive reaction for lipids showing presence of cuticle even in in vitro leaves. Only autotrophic palm leaves showed idioblasts containing calcium oxalate crystals.
\end{abstract}

Key words: Cocos nucifera, in vitro culture, polysaccharides, protein, lipids.

\section{RESUMO}

Este trabalho fornece informações sobre resultados de testes histoquímicos em folhas e embriões zigóticos de 'coqueiro anão' (Cocos nucifera). Foram comparadas folhas de palmeiras de cultura in vitro e autotróficas. Reações para polissacarídeos insolúveis e compostos acídicos, proteínas, lipídios, lignina e outras classes de compostos foram testadas por meio de testes histoquímicos. Nenhuma amostra foi positiva para lignina e compostos fenólicos. Todas as amostras foram positivas para proteína, amido e polissacarídeos insolúveis, enquanto compostos acídicos foram observados apenas em folhas cultivadas in vitro. Amostras de folhas in vitro $e$ autotróficas apresentaram reação positiva para lipídios, demonstrando a presença de cutícula mesmo em plântulas in vitro. Somente folhas de palmeiras autotróficas apresentaram ideoblastos contendo cristais de oxalato de cálcio.

\begin{abstract}
Palavras-chave: Cocos nucifera, cultura in vitro, polissacarídeos, proteínas, lipídios.
\end{abstract}

\section{INTRODUCTION}

The coconut palm (Cocos nucifera L.) is one of the most important lowland tropical crops, providing copra and coconut oil for the home and international markets (SANTAMARÍA et al., 1999). In Brazil, the coconut crop occupies a cultivated area of almost 300 thousand hectares, with a production of 245 thousand tons, principally on sandy lands situated along the coast that extend from Pará to Rio de Janeiro states (FNP, 2002). On the other hand, around the world, the coconut production is diminishing due to decline in the productivity, and this fact is caused by palm aging, natural calamities such as diseases and drought, lack of well adapted varieties and with high productivity, and genetic erosion (SÁENZ et al., 1999). According to THANH-TUYEN \& DE GUZMAN (1983), the problems encountered in conventional coconut breeding for high-yielding ability are those associated with its long life-span and heterozygosity, and consequently, the production of inbred lines is a long and difficult process. Thus, unconventional methods have to be evolved to shorten the inbreeding cycle (HORNUNG, 1995).

Coconut in vitro zygotic embryo cultivation was reported by DE GUZMAN \& DEL ROSÁRIO(1964)

\footnotetext{
IDepartamento de Biologia, Centro de Ciências Biológicas e da Saúde, Universidade Federal de Sergipe (UFS), 49100-000, Aracajú, SE, Brasil. E-mail: mar@ufs.br. Autor para correspondência.

IUniversidade Estadual de Santa Cruz (UESC), Ilhéus, BA, Brasil.

IIIUniversidade Estadual do Norte Fluminense Darcy Ribeiro (UENF), Campos dos Goytacazes, RJ, Brasil.
} 
for the 'Makapuno' coconut. Under natural conditions the seed endosperm degraded, depriving the developing embryo of necessary nutrients. Attempts have been made since then to overcome the difficulties in obtaining normal plants and in the acclimatization stage (RILLÓ, 1999). Nowadays tissue culture has been performed in coconut on seedling and mature tissue explants (BRANTON \& BLAKE, 1983) including zygotic embryos (SANTAMARÍA et al., 1999), in order to have non-heterozygous, high yielding disease-resistant clonal coconut plantlets that could provide uniform material for marketing mainly for replacement planting and high-quality parental stocks for breeding programs (BRANTON \& BLAKE, 1983).

The morphology of plants cultivated in vitro is greatly affected by this environment. Problems appear such as little or no epicuticular wax formation; bad stomata functioning (ZIV, 1995), low chlorophyll content, low percentage of dry matter, few stomata, low photosynthetic ability and incomplete root development and/or low lateral root development (KOSAI, 1991). Anatomical and histochemical studies are important mainly when plants cultivated in vitro are compared to autotrophic plants, in order to evaluate the existence of differences in reserve substance accumulation and presence or absence of other substances that are involved in plant survival mechanisms or that may make them less competitive. Therefore the objective of the present study was to characterize the most adequate embryo for in vitro culture and to compare the anatomical and histochemical characteristics of leaves from vitroplants and from plants cultivated in a greenhouse, and to investigate whether leaves were modified internally as a consequence of development in such a culture environment.

\section{MATERIAL AND METHODS}

Coconut (Cocos nucifera L.) belonging to the ecotype 'Coqueiro Anão' was used in this study due to its autogamous reproduction, with low heterogeneity among zygotic embryos. Eleven-monthold fruits were collected from the Experimental Field of PESAGRO in Campos dos Goytacazes, RJ, Brazil. Part of these fruits was grown in a greenhouse using washed sand as substrate, and the other part was used for embryo extraction and in vitro culturing. Ten to twelvemonth-old embryos and six-month-old leaves after emission were collected and used for histochemical tests.

After sterilization, the embryos were cultivated in Y3 medium (EEUWENS, 1976) supplemented with the MOREL \& WETMORE (1951) vitamins, $100 \mathrm{mg} \mathrm{L}^{-1}$ casein hydrolysate, $6 \%$ sucrose, $100 \mathrm{mg} \mathrm{L}^{-1}$ myo-inositol, $1 \mathrm{mg} \mathrm{L}^{-1}$ activated charcoal and $6 \%$ agar. The $\mathrm{pH}$ was adjusted to 5.8 before autoclaving. Excised embryos were cultivated in essay tubes ( $25 \mathrm{~mm}$ $x$ 150mm) until 30 cultivation days (DAI), when the plantlets were transferred to culture medium without agar. By 90DAI, sucrose was reduced to 0.3 per cent, and the plantlets were transferred on to $100 \mathrm{Ml}^{-1}$ medium in $600 \mathrm{Ml}^{-1}$ culture bottles.

Leaves from in vitro culture and the greenhouse, and embryos were fixed in $2.5 \%$ glutaraldehyde and 4\% formaldehyde in sodium cacodilate buffer $(0.1 \mathrm{M}, \mathrm{pH} 7.2)$ for $1 \mathrm{~h}$ at room temperature, then kept at $4^{\circ} \mathrm{C}$ until use. After rinsing in buffer they were dehydrated in a graded ethanol series (30 to 100\%). The material was infiltrated and embedded in Paraplast ${ }^{\circledR}$ using xylol as transition solvent. Ten $\mu \mathrm{m}$ thick sections were obtained with a rotatory microtome. Sections were stretched on glass slides previously treated with Haupt gelatin fixative (HAUPT, 1930) and $8 \%$ formalin, and exposed to a xylol-ethanol series to remove the Paraplast ${ }^{\circledR}$. For anatomical observation, embryos and leaf sections were stained using astra blue and basic fuchsine (ROESER 1972, modified by LUQUE et al., 1996). They were then mounted in Canada balsam. The observations and photographs were performed on an Olympus B202 optical microscope.

Sections were stained for insoluble carbohydrates with $1 \%$ periodic acid-Schiff (PAS) and mounted in Canada balsam; starch and some polysaccharides of the cell wall showed red or magenta colors (O'BRIEN \& MCCULLY, 1981). For control, the periodic acid was omitted and glass slides were immersed in $\alpha$-amylase for $2 \mathrm{~h}$ at $37^{\circ} \mathrm{C}$ (MCMANUS, 1946). For pectic substances (acidic polysaccharides) localization, sections were stained with ruthenium red, counterstained with methylene blue and mounted in Canada balsam, and the test was considered positive if red color was observed (LANGERON, 1949). Sections were stained for starch with IKI solution and mounted in 50\% glycerol; the test was considered positive if a blue-black or dark brown color was observed (JOHANSEN, 1940). For lipids localization, sections were kept in 95\% ethanol, immersed in 2\% Sudan IV in 95\% ethanol for $30 \mathrm{~min}$ and mounted in $50 \%$ glycerol, and the test was considered positive if a red-pink or pink color was observed (GERLACH, 1984). For calcium carbonate localization, $10 \%$ glacial acetic acid drops were deposited on sections free of Paraplast ${ }^{\circledR}$; the test is considered positive when there is elimination of carbonic gas bubbles (CHAMBERLAIN, 1932, modified by KRAUS \& ARDUIN, 1997). For calcium oxalate, $10 \%$ 
hydrochloric acid was utilized, and the test was considered positive if the crystals were soluble in the acid and the same not occur in the presence of acetic acid glacial (CHAMBERLAIN, 1932, modified by KRAUS \& ARDUIN, 1997).

\section{RESULTS AND DISCUSSION}

Different morphology was observed in the leaves from plants cultivated in vitro (Figure 1) and from plants cultivated in the greenhouse (Figure 2). Sections of leaves from plants cultivated in the greenhouse showed the layer of palisade cells wellorganized and some of these cells underwent periclinal division; well-developed cuticle; presence of idioblasts containing crystals (Figure 3). Sections from plants cultivated in vitro displayed irregularly shaped palisade cells of different sizes and with wavy anticlinal wall and absence of idioblasts containing crystals. Both in plants cultivated in vitro and in the greenhouse, some cells of photosynthetic parenchyma were detected containing substances which showed different staining degree in relation to others, even though on sections from vitroplants these same cells stained less. Only eleven- and twelve-month-old embryos showed two well-developed meristematic zones which resembled the shoot and root poles, as well as a developing cotyledon (or haustorium). It was possible to observe a well-differentiated apex and plumular tissue in twelvemonth-old embryos (Figure 4).

The PAS reaction was positive for insoluble carbohydrates in leaves from in vitro culture (Figure 5) and the greenhouse (Figure 6), showing the presence of polysaccharides in the cell wall and cytoplasm, principally in the photosynthetic parenchyma. The same reaction was observed in the twelve-month-old embryo (embryo axis and cotyledon) but the apex stained intensely indicating high metabolic activity (Figure 4). The control samples for PAS did not stain. The reaction for starch was positive for embryos. It was possible to observe starch grains in the cotyledons, located close to the cellular wall. Starch was observed in the mesophyll from the leaves of plants cultivated in vitro (Figure 7) and from the leaves of plants cultivated in the greenhouse (Figure 8). In the samples from the leaves of plants cultivated in vitro, starch grains were observed in the palisade and chlorophyllian (spongy) tissues, while in the samples of plants grown in the greenhouse, the grains of starch were observed in the chlorophyllian tissue.

Lipids were located in the cuts of all the leaf samples (Figure 9 - 10), with denser staining on the epidermis of the leaves of plants cultivated in the greenhouse, and weaker in the epidermis of the leaves of plants cultivated in vitro, demonstrating the cuticle presence. Pectic substances (acidic polysaccharides) were located on the epidermis and mesophyll only in the in vitro leaf samples (Figure 11) but in leaves of plants cultivated in the greenhouse and in embryos it was only observed the color of methylene blue (Figure 12). The tests with hydrochloric acid demonstrated the presence of calcium oxalate (Figure 3), since the crystals found in the leaves from plants cultivated in the greenhouse were dissolved without the presence of effervescence, and they continued intact in the presence of acetic acid.

The PAS reaction for insoluble carbohydrates stained more intensely in twelve-monthold embryos (embryo axis and cotyledon), and they were considered mature and qualified to be cultured in vitro. According to DE SOUZA (1998), carbohydrates play an important role in biological systems, associating among themselves and forming a macromolecular complex which has an important functional role, not only acting as a metabolite reserve in the cells, but also participating in the phenomenon of cellular recognition. It has been demonstrated that many vital processes such as germination and embryogenesis are influenced by sugar (JANG \& SHEEN, 1997).

In palm trees, even when the fruit ripens, the embryo can have little differentiation (CORNER, 1966). The germination irregularity of in vitro coconut embryos may be caused by the embryo immaturity. In this study, about $50 \%$ of the embryos obtained from mature seeds were still little developed, with a different structure from that described for the mature embryo, with small and with poorly developed cotyledons.

The coconut embryo is cylindrical and divided into parts by a small constriction in the median region; the plumule-root axle is found in the apical part of the cotyledon (SREEKUMARI KARTHA, 1981). Coconut zygotic embryo development was studied by HACIUS \& PHILIP (1979) who concluded that there was not just a bipolar structure with stem and root meristem but there was also a cotyledon meristem. During the embryo development, the cotyledon is the predominant tissue. At the mature stage, the cotyledon increases in volume so that the stem and root premordials are proportionally insignificant. These data corroborate the idea that the 12- month-old embryo described in this study was already at the mature stage. The morphological aspect of the embryo presented in this work is similar to that presented by HORNUNG (1995).

The results of this study for the plantlet leaves cultivated in vitro showed disarrangement in 


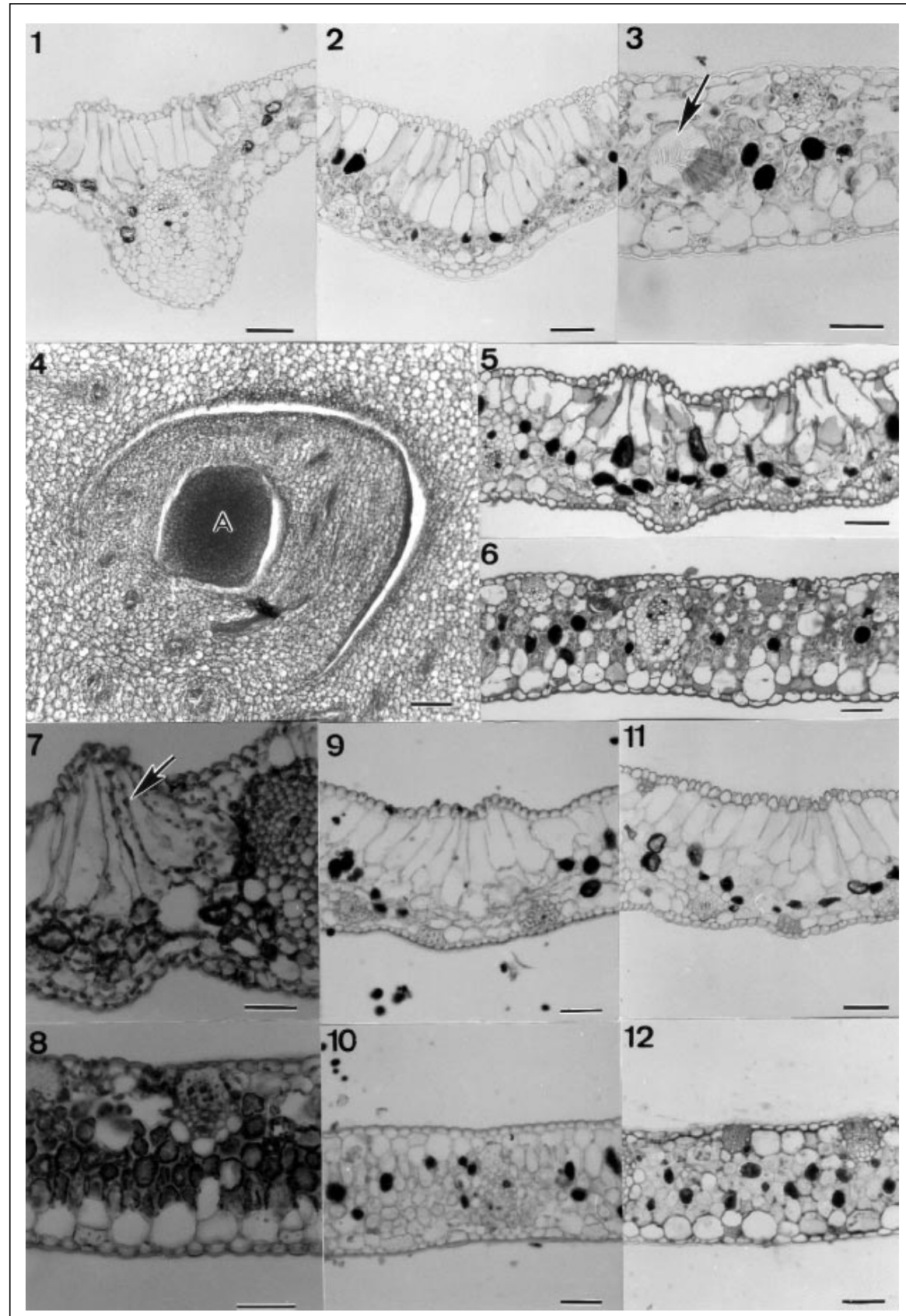

Figure 1 - Histochemical staining reactions in leaves and embryos of Cocos nucifera. 1: Leaf from plants cultivated in vitro; 2: Leaf from plant cultivated in the greenhouse; 3: Detail of mesophyll showing calcium oxalate crystals (arrow); 4: Embryo tissue stained with PAS reagent for total insoluble polysaccharides with the apex (A) stained intensely; 5: Leaf from plants cultivated in vitro tissue stained with PAS reagent; 6: Leaf from plants cultivated in the greenhouse stained with PAS reagent; 7: Leaf from plants cultivated in vitro tissue showing grains of starch in the palisade (arrow) and chlorophyllian tissues; 8: Leaf from plants cultivated in the greenhouse showing grains of starch in the chlorophyllian tissue; 9: Leaf from plants cultivated in vitro tissue showing positive reaction for lipids demonstrating the cuticle presence; 10: Leaf from plants cultivated in the greenhouse showing presence of cuticle; 11: Leaf from plants cultivated in vitro tissue demonstrating positive reaction for Pectic substances (acidic polysaccharides) on the epidermis and mesophyll; 12: Leaf from plants cultivated in vitro showing only counterstain. Bar $=50 \mathrm{~mm}$. 
the tissue structure especially in the palisade parenchyma that presented a very irregular architecture. These results are in line with the literature, and several authors have reported anomalies in in vitro cultivated plants (SANTAMARIA et al., 1999, CARVALHO et al., 2001). The modification of internal leaf structure in response to environmental conditions is a known phenomenon (GROUT \& ASTON, 1978). No increase was observed in coconut in the number of palisade tissue layers compared to the plants cultivated in a greenhouse, unlike observations by FIDELIS et al. (2000) in Brosimum gaudichaudii Tréc.

Leaves from micropropagated plants in a conventional cultivation system, confined in the hermetically closed recipients, and under low photosynthetic active radiation and high relative humidity, were small, thin and sometimes translucent with little development of the epidermis tissue and the mesophyll (ZIV, 1995). The stomata apparatus of the epidemic tissue of micropropagated plants differed greatly from the plants cultivated in a greenhouse or in the field. In several species studied, the meristem of the leaf cultivated in vitro had poorly formed palisade tissue consisting mainly of spongy parenchyma with large intercellular air spaces.

The leaf cuts from coconut plants cultivated in the greenhouse corresponded to coconut leaf descriptions reported by several authors, in transversal cuts the smooth upper epidermis was formed by a line of cutinized cells. The adaxial epidermis was uniform, with cells varying from more or less rectangular or cubic longitudinally. The leaf center or mesophyll was occupied by the palisade parenchyma. The lower epidermis is slightly grooved with short, sparse, trichomes (PURSEGLOVE, 1979). Raphides bundles were observed as described for the family Palmae (PRYCHID \& RUDALL, 1999).

Differences were observed in starch accumulation. In the leaves of plants cultivated in the greenhouse, starch was observed only in the spongy chlorophyll tissue. However, in those cultivated in vitro, starch was observed in the palisade parenchyma and chlorophyll. Most plants store starch or sucrose as reserve carbohydrates, but others storage fructans that may have functions other than carbon storage; they have been implicated in protecting plants against water deficit (VIJN \& SMEEKENS, 1999).

Cuticle presence was detected in the leaves of plants cultivated in the greenhouse and in vitro, but in the latter, the cuticle was thinner. This result is in line with reports in the literature, that has reported poor cuticle formation in in vitro plants (SANTAMARIA et al., 1999). The main difference between young leaves developed in vitro or ex vitro was a thinner lamellate zone for ex vitro cuticles, and the cuticle thickness of expanded leaves was greater for in vitro cuticles suggesting a temporary decrease in cuticle biosynthesis after plant transfer from in vitro to $e x$ vitro (GILLY et al., 1997). According REPELLIN et al. (1997), the composition of coconut leaf lipids is similar to that of higher plants of the so-called '18:3 ( $\alpha$ linolenic)' group. Lipids are present in plants participating in protection mechanisms against water loss, in the form of waxes on the leaf epidermis, for example, and are directly involved in the adaptation to drought stress (REPELLIN et al., 1997).

Twelve-month-old embryos (embryo axis and cotyledon) presenting well- differentiated apex and plumular tissue were considered mature and qualified to be cultured in vitro. Sections of leaves from plants cultivated in vitro showed structural disarrangement in the palisade cells, presence of starch in the palisade tissue, acidic polysaccharides located on the epidermis and mesophyll, and epidermis with cuticle denser when compared to plants cultivated in the greenhouse. The differences were observed as a consequence of development in the culture environment.

\section{CONCLUSION}

Twelve-month-old embryos (embryo axis and cotyledon) presenting well- differentiated apex and plumular tissue were considered mature and qualified to be cultured in vitro. Sections of leaves from plants cultivated in vitro showed structural disarrangement in the palisade cells, presence of starch in the palisade tissue, acidic polysaccharides located on the epidermis and mesophyll, and epidermis with cuticle denser when compared to plants cultivated in the greenhouse. The differences were observed as a consequence of development in the culture environment.

\section{REFERENCES}

BRANTON, R.L.; BLAKE, J. Development of organized structures in callus derived from explants of Cocos nucifera L. Annals of Botany, v.52, p.673-678, 1983.

CARVALHO, V.L. et al. Influência de diferentes níveis de produção sobre a evolução da ferrugem do cafeeiro e sobre teores foliares de compostos fenólicos. Ciência e Agrotecnologia, v.25, p.49-54, 2001.

CHAMBERLAIN, C.J. Methods in plant histology. Chicago: University of Chicago, 1932. 328p.

CORNER, E.J.H. The natural history of palms. Los Angeles: University of California, 1966. 393p. 
DE GUZMAN, E.V.; DEL ROSARIO, D.A. The growth and development of Cocos nucifera L. 'Macapuno' embryos in vitro. Philipine Agriculture, v.48, p.82-94, 1964.

DE SOUZA, W. Citoquímica de carboidratos. In: DE SOUZA, W. Técnicas básicas de microscopia eletrônica aplicadas às ciências biológicas. Rio de Janeiro: Sociedade Brasileira de Microscopia, 1998. Cap.3, p.66-73.

EEUWENS, C.J. Mineral requirement for growth and callus initiation of tissue explants excised from mature coconut palms (Cocos nucifera) and cultured in vitro. Physiology Plantarum, v.36, p.23-38, 1976. Available from: <http:// www3.interscience.wiley.com/journal/119641720/issue> Accessed: jan. 15, 2010. doi: 10.1111/j.1399-3054.1976.tb05022.x.

FIDELIS, I. et al. Características anatômicas de estruturas vegetativas de Brosimum gaudichaudii Tréc. desenvolvidas in vitro e ex vitro. Ciência e Agrotecnologia, v.24, p.327-336, 2000 .

FNP $^{\circledR}$ Consultoria e Comércio. Agrianual. Available from: www.fnp.com.br. 2002. Accessed: jan. 15, 2010.

GERLACH, D. Botanische mikrotechnik. Stuttgart : Georg Thieme Verlag, 1984. 311p.

GILLY, C. et al. Ultrastructure and radiolabellig of leaf cuticles from ivy (Hedera helix L.) plants in vitro and during ex vitro acclimatization. Annals of Botany, v.80, p.139-145, 1997. Available from: <http://aob.oxfordjournals.org/cgi/reprint/80/ 2/139>. Accessed: jan. 15, 2010. doi: 10.1006/ anbo.1997.0414.

GROUT, B.W.W.; ASTON, M.J. Modified leaf anatomy of cauliflower plantlets regenerated from meristem culture. Annals of Botany, v.42, p.993-995, 1978.

HACIUS, B.; PHILLIP, V.J. Embryo development in Cocos nucifera L. - A critical contribution to a general understanding of palm embryogenesis. Plant Systematics and Evolution, v.132, p.91-106, 1979. Available from: http:// w w w.springe r link. c om/content/104878/ ? Copyright $=1979 \&$ sortorder $=$ asc $\& v=$ condensed $\& o=10$. Accessed: jan. 15, 2010. doi:10.1007/BF00983086.

HAUPT, A.W. A gelatin fixative for paraffin sections. Stain Technology, v.5, p.97-98, 1930.

HORNUNG, R. Micropropagation of Cocos nucifera L. from plumular tissue excised from mature zygotic embryos. Plantations, Recherche, Développement, v.2, p.38-41, 1995.

JANG, J-C; SHEEN, J. Sugar sensing in higher plants. Trends in Plant Science, v.2, p.208-214, 1997.

JOHANSEN, D.A. Plant microtechnique. New York: McGraw-Hill Book, 1940. 523p.

KOSAI, T. Micropropagation under photoautotrophic conditions. In: DEBERGH, P.C.; ZIMMERMAN, R.H. Micropropagation - Technology and application. Dordrecht: Kluwer Academic Publisher, 1991. Cap.12, p.447469.

KRAUS, J.E.; ARDUIN, M. Manual básico de métodos em morfologia vegetal. Rio de Janeiro: Universidade Rural, 1997. 198p.

LANGeron, M. Précis de microscopie. Paris: Masson et Cie, 1949. 916p.
LEON, J. Fundamentos botanicos de los cultivos tropicais. San José: IICA, 1968. 478p.

LUQUE, R. et al. Métodos de coloração de ROESER (1972) modificado e Kropp (1972) visando a substituição do azul de astra pelo azul de alcião 8GS ou 8GX. Acta Botanica Brasilica, v.10, p.199-212, 1996.

MCMANUS, J.F.A. Histological demonstration of mucin after periodic acid. Nature, v.158, p.202, 1946. Available from: <http://www.nature.com/nature/journal/v158/n4006/pdf/ 158202a0.pdf $>$. Accessed: jan. 16, 2010. doi:10.1038/ $158202 \mathrm{a} 0$.

MOREL, G.M.; WETMORE, R.H. Fern callus tissue culture. American Journal of Botany, v.38, p.141-143, 1951.

O'BRIEN, T.P.; MCCULLY, M.E. The study of plant structure: principles and selected methods. Melbourne: Termarcarphi Pty, 1981. 352p.

PRYCHID, C.J.; RUDALL, P.J. Calcium oxalate crystals in monocotyledons: A review of their structure and systematics. Annals of Botany, v.84, p.725-739, 1999. Available from: $<$ http://aob.oxfordjournals.org/content/vol84/issue6/index.dtl >. Accessed: jan. 15, 2010. doi: 10.1006/anbo.1999.0975.

PURSEGLOVE, J.W. Tropical crops: monocotiledons. London: Longman, 1979. 607p.

REPELLIN, A. et al. Leaf membrane lipids and drought tolerance in young coconut palms (Cocos nucifera L.). European Journal of Agronomy, v.6, p.25-33, 1997.

RILLÓ, E. Coconut embryo culture. In: OROPEZA C. et al. Current advances in coconut biotechnology/Current Plant science and biotechnology in agriculture. Dordrecht: Kluwer Academic, 1999. Cap.8, p.279-288.

ROESER, K.R. Die Nadel der schwarzkiefer. massenprodukt und künstwerk der natur. Mikrokosmos, v.61, p.33-36, 1972.

SÁENZ, L. et al. Somatic embryogenesis and regeneration in coconut from plumular explants. In: OROPEZA C. et al. Current advances in coconut biotechnology/Current plant science and biotechnology in agriculture. Dordrecht: Kluwer Academic, 1999. Cap.10, p.309-320.

SANTAMARÍA, J.M. et al. Effect of medium sucrose on photosyntetic capacity of coconut vitroplants formed from zygotic embryos. In: OROPEZA C. et al. Current advances in coconut biotechnology/Current Plant science and biotechnology in agriculture. Dordrecht: Kluwer Academic, 1999. Cap.13, p.371-381.

SREEKUMARI KARTA, A. Embryo of coconut and its germination. Journal of Plant Crops, v.9, p.125-127, 1981.

THANH-TUYEN, N.T.; DE GUZMAN, E.V. Formation of pollen embryos in cultured anthers of coconut (Cocos nucifera L.). Plant Science Lettera, v.29, p.81-88, 1983.

VIJN, I.; SMEEKENS, S. Fructan: more than a reserve carbohydrate? Plant Physiology, v.120, p.351-359, 1999. Available from: <http://www.plantphysiol.org/cgi/content/full/ 120/2/351>. Accessed: jan. 16, 2010. doi: 10.1104/ pp.120.2.351.

ZIV, M. In vitro acclimatization. In: AITKEN-CHRISTIE, J. et al. Automation and environmental control in plant tissue culture. Dordrecht: Kluwer Academic, 1995. p.493538. 